ARCHIWUM FILOZOFII PRAWA I FILOZOFII SPOŁECZNEJ JOURNAL OF THE POLISH SECTION OF IVR

\title{
Obrazy prawa w sztuce filmowej. Wprowadzenie
}

Niniejszy zeszyt „Archiwum Filozofii Prawa i Filozofii Społecznej” poświęcony jest problematyce związków prawa i filmu. Ponieważ - co do zasady - obszar ten nie był do tej pory przedmiotem zainteresowania polskiego prawoznawstwa (choć są w tym zakresie wyjątki), warto powiedzieć kilka słów o tym, dlaczego w naszym przekonaniu na zainteresowanie takie zasługuje. W tym krótkim wstępie możemy oczywiście wskazać jedynie wybrane powody, choć będzie to lista dalece niekompletna.

Pierwszy argument odwołuje się do stanu badań współczesnej humanistyki. Trzeba bowiem zauważyć, że problematyka filmowa jest obszarem wyodrębnionej refleksji filozoficznej przynajmniej od lat 70. XX w., zaś w latach 90. doczekała się już ona poświęconych sobie czasopism filozoficznych ${ }^{1}$. Na reakcję prawoznawstwa nie trzeba było długo czekać - ostatnia dekada minionego wieku to także czas znacznego przyrostu liczby publikacji prawniczych poświęconych problematyce związków prawa i filmu². Unikając w tym miejscu zadania - wykonanego już przez innych autorów ${ }^{3}$ - rekonstrukcji ścieżek rozwoju refleksji prawniczo-filmowej odnotujmy tylko, że mamy do czynienia z ugruntowaną już, choć relatywnie młodą, perspektywą badawczą.

Drugi z argumentów odwołuje się do edukacyjnego aspektu problematyki prawno-filmowej. Warto przypomnieć, że ważnym elementem poznawania i rozumienia prawa jako pewnego złożonego mechanizmu regulowania relacji międzyludzkich jest - jak wskazuje Hans-Georg Gadamer ${ }^{4}$ - uwzględnienie elementu zastosowania. Zastosowanie takie z kolei powinno być ujmowane nie tylko jako aplikacja prawa do konkretnych stanów faktycznych, lecz także jako odniesienie do realiów i problemów społeczno-kulturowych. Wynika z tego, że refleksja prawno-filmowa, sprzyjająca tego rodzaju odniesieniom, może być pożytecznym ćwiczeniem w rozumieniu prawa.

Tym samym docieramy do trzeciego z argumentów. Nowoczesne prawo, rozumiane jako zinstytucjonalizowany porządek normatywny, jest systemem w wysokim stopniu refleksyjnym ${ }^{5}$; tymczasem rozważania filmowo-prawne sprzyjają takiej refleksyjności. Pozwalają one bowiem na spojrzenie na prawo i jego społeczne funkcjonowanie z innej perspektywy, odmiennej od czysto wewnętrznego, jurydycznego punktu widzenia. Jeśli

Zob. czasopisma: „Film \& Philosophy” oraz „Film-Philosophy”.

Zob. S. Machura, P. Robson, Law and Film: Introduction, ,Journal of Law and Society” 2001/1, s. 3-8.

Zob. J. Kuisz, Od „prawa i literatury” do „prawa i filmu”? Uwagi o możliwości badań nad historiq audiowizualnej kultury prawnej, w: J. Kuisz, M. Wąsowicz (red.), Prawo i literatura. Antologia, Warszawa 2019, s. 15-36. Zob. też artykuł Kamila Zeidlera, otwierający ten zeszyt „Archiwum”. Wydaje się, że najbardziej znanym polskim opracowaniem lokującym się w obszarze prawo i film jest książka Jacka Duboisa: J. Dubois, Mordowanie na ekranie, Warszawa 2016.

4 H.-G. Gadamer, Prawda i metoda. Zarys hermeneutyki filozoficznej, Warszawa 2004, s. 443-465. Zob. też P. Jabłoński, Na czym polega poznawanie prawa? O konsekwencjach myśli Gadamerowskiej dla edukacji prawniczej, „Krytyka Prawa. Niezależne studia nad prawem" 2016/3, s. 41-55.

5 Zob. M. Pichlak, Refleksyjność prawa. Od teorii spotecznej do strategii regulacji i z powrotem, Łódź 2019. 
dzieła filmowe niosą w sobie obserwacje prawa i świata prawniczego, to prawo, obserwując te obserwacje, jest prowokowane do refleksji nad sobą samym. Dzięki takiej, by sparafrazować Paula Ricoeura, „okrężnej drodze refleksji” zapośredniczonej w badaniu wytworów kultury (w tym wypadku: obrazów filmowych) możliwe jest, jak sądzimy, zrozumienie prawa w bardziej refleksyjny i krytyczny, a przez to - głębszy sposób.

Z pewnością nie da się więc sprowadzić kierunku ,prawo i film” wyłącznie do badań nad tym, jak dzieła audiowizualne wpływają na popularną świadomość prawną. Można niekiedy odnieść wrażenie, że kierunek ten bywa sprowadzany - w pewnym uproszczeniu - do odpowiedzi na takie właśnie pytanie: „Czego laicy uczą się z filmów o prawie (i dlaczego się mylą)?". Nie jest naszym zamiarem deprecjonowanie prowadzonych pod takim szyldem analiz; stanowią one rzeczywiście istotną część filmowo-prawnych badań. Znacznie ciekawsze wydaje się jednak pytanie, czego z filmów mogą się nauczyć o prawie sami juryści - czy też, ujmując nieco bardziej metaforycznie, czego prawo może się dowiedzieć o sobie samym. Formułując zaproszenie do niniejszego zeszytu, pytaliśmy w tym duchu: „Czy film, jako jedna z bardziej dziś popularnych dziedzin kultury, może być środkiem powiedzenia o prawie czegoś interesującego i wartościowego?". Jakkolwiek wydaje nam się, że Autorom zebranych tu tekstów udało się odpowiedzieć na to pytanie twierdząco, to ostateczną ocenę pozostawiamy Czytelnikom.

Zarysowane wyżej zadania spełniają w pierwszej kolejności, co oczywiste, filmy zaliczane do typowo „prawniczych” podgatunków, takich jak lawyer movies czy courtroom dramas ${ }^{7}$. Stąd też nie dziwi, że to właśnie one stoją w centrum zainteresowań przedstawicieli kierunku „prawo i film”, co poniekąd znajduje swój wyraz także w opracowaniach zawartych w niniejszym zeszycie. Warto jednak odnotować, że „obrazy prawa” mogą być malowane także w tych dziełach, które wprost nie odnoszą się do realnie funkcjonujących porządków prawnych. $\mathrm{Z}$ taką sytuacją mamy do czynienia w co najmniej trzech przypadkach. Po pierwsze, chodzi tu o filmy obrazujące funkcjonowanie fikcyjnych porządków polityczno-prawnych, z czym w szczególności spotykamy się w nurcie kina science-fiction (by wspomnieć tylko takie klasyczne przykłady jak Łowca androidów ${ }^{8}$, Matrix ${ }^{9}$ czy Raport mniejszośc $\left.i^{10}\right)$. Po drugie, mogą to być obrazy ukazujące inne niż prawo instytucje, czy porządki normatywne, które - potraktowane na prawach metafory bądź analogii - możemy odczytać jako ilustrujące „nasz” system prawny. Jednego z najbardziej znanych przykładów dostarcza tu trylogia Ojciec chrzestny ${ }^{11}$, przedstawiająca system funkcjonowania mafii w Stanach Zjednoczonych; inne tytuły, które można przywołać to choćby Lot nad kukutczym gniazdem ${ }^{12}$, a na rodzimym gruncie - film Dreszcze ${ }^{13}$.

6 Zob. zwłaszcza P. Ricoeur, Hermeneutyka symboli a refleksja filozoficzna - II, w: P. Ricoeur, Egzystencja i hermeneutyka. Rozprawy o metodzie, Warszawa 2003, s. 121-127.

Więcej na temat podgatunków filmów „prawniczych” zob. J. Kuisz, Od „prawa i literatury”..., s. 17-21.

8 R. Scott (reż.), Łowca androidów [Eng. Blade Runner] (film kinowy), The Ladd Company-Shaw Brothers, USA-Hong Kong 1982.

9 L. i E. Wachowscy (reż), Matrix (film kinowy), Warner Bros Pictures-Village Roadshow Pictures-Groucho II Film Partnership-Silver Pictures, USA-Australia 1999.

10 S. Spielberg (reż.), Raport mniejszości [Eng. Minority Report] (film kinowy), 20th Century Fox-DreamWorks SKG, USA 2002.

${ }_{11}$ F.F. Coppola (reż.), Ojciec chrzestny [Eng. The Godfather] (film kinowy), Paramount Pictures-Alfran Productions, USA 1972; F.F. Coppola (reż.), Ojciec chrzestny II [Eng. The Godfather. Part II] (film kinowy), Paramount Pictures-The Coppola Company, USA 1974; F.F. Coppola (reż.), Ojciec chrzestny III [Eng. The Godfather. Part III] (film kinowy), Paramount Pictures-Zoetrope Studios, USA 1990.

12 M. Forman (reż.), Lot nad kukutczym gniazdem [Eng. One Flew Over the Cuckoo's Nest] (film kinowy), Fantasy Films, USA 1975.

13 W. Marczewski (rè̇.), Dreszcze (film kinowy), Zespół Filmowy „Tor”, Polska 1981. 
Przy czym sugerowany tu sposób odczytywania tego rodzaju dzieł, jako metaforycznych ilustracji funkcjonowania porządku prawnego, pozostaje rzecz jasna niezależny od tego, czy taki właśnie był pierwotny zamysł ich twórców. Po trzecie wreszcie, należy wyróżnić takie filmy, które obrazują czy komentują istotne problemy polityczne, gospodarcze lub społeczne - problemy, na które prawo udziela (lub powinno udzielać) odpowiedzi. Jak wskazują również teksty publikowane w tym zeszycie, może tu chodzić o niezmiernie zróżnicowane kwestie: od prawnych aspektów transformacji ustrojowej, poprzez kwestie stosunków pracy i kultury konsumpcyjnej, po problematykę prawnej regulacji (konstytuowania?) relacji intymnych.

Dodajmy jeszcze słowo o strukturze tej publikacji. Teksty pogrupowane zostały według sposobu, w jaki odnoszą się one do problematyki „prawo i film”. I tak, w pierwszej grupie (Kamil Zeidler, Marta Dubowska) Czytelnik znajdzie artykuły skoncentrowane wokół charakterystyki interesującego nas w tym tomie pola badawczego. Na drugą część artykułów (Tomasz Widłak, Paweł Jabłoński, Katarzyna Krzyżanowska, Szymon Osmola) składają się opracowania poświęcone zadaniu przyjrzenia się pewnym istotnym właściwościom prawa w oparciu o wybrany materiał filmowy. Trzecia wreszcie grupa tekstów (Karolina Kocemba, Mateusz Grabarczyk, Marlena Drapalska-Grochowicz) dotyczy już nie tyle bezpośrednio samego prawa, ile wybranych, prawnie relewantnych zjawisk społeczno-kulturowych. O ile więc pierwsza część artykułów ma charakter metateoretyczny, o tyle dwie pozostałe stanowią próbki przedmiotowych aplikacji.

Na koniec chcieliśmy podziękować Redakcji „Archiwum” za to, że wykazała życzliwość i zainteresowanie dla naszego pomysłu wydania zeszytu filmowego tego kwartalnika, a także anonimowym Recenzentom, których oceny i uwagi były ważnym elementem składowym procesu formowania się tej publikacji.

Paweł Jabłoński ${ }^{14}$, Maciej Pichlak ${ }^{15}$

Wrocław, luty $2021 \mathrm{r}$.

14 Numer ORCID: 0000-0002-9562-4419. Adres e-mail: pawel.jablonski@uwr.edu.pl

15 Numer ORCID: 0000-0001-5113-9537. Adres e-mail: maciej.pichlak@uwr.edu.pl 


\section{BIBLIOGRAFIA / REFERENCES:}

Dubois J. (2016). Mordowanie na ekranie. Warszawa: C. H. Beck.

Gadamer, H.-G. (2004). Prawda i metoda. Zarys hermeneutyki filozoficznej. Warszawa: Wydawnictwo Naukowe PWN.

Jabłoński, P. (2016). Na czym polega poznawanie prawa? O konsekwencjach myśli Gadamerowskiej dla edukacji prawniczej. Krytyka Prawa. Niezależne studia nad prawem 3, 41-55.

Kuisz, J. (2019). Od „prawa i literatury” do „prawa i filmu”? Uwagi o możliwości badań nad historią audiowizualnej kultury prawnej. In J. Kuisz, M. Wąsowicz (eds.), Prawo i literatura. Antologia. Warszawa: Scholar.

Machura, S., Robson, P. (2001). Law and Film: Introduction. Journal of Law and Society 1, 1-8.

Pichlak, M. (2019). Refleksyjność prawa. Od teorii społecznej do strategii regulacji i z powrotem. Łódź: Wydawnictwo Uniwersytetu Łódzkiego.

Ricoeur, P. (2003). Hermeneutyka symboli a refleksja filozoficzna - II. In P. Ricoeur, Egzystencja i hermeneutyka. Rozprawy o metodzie. Warszawa: DeAgostini. 